\title{
Humanitarian Intervention in Libya: Legal Analysis of the UNSC Resolutions and Jurisdiction of ICC with Linkage to Contemporary Challenges in National Security of Pakistan
}

\author{
Sardar M. A. Waqar Khan Arif \\ Lecturer Dept. of Law, University of Kotli Azad Jammu and Kashmir \\ PhD Candidate at IIUI, Pakistan-cum-Rijks Universiteit Groningen, The Netherlands \\ PO Box 72, Groningen 9700 AS, The Netherlands \\ Tel: 92-333-570-69-28Ｅ-mail: sardarwaqarkhan@gmail.com

\begin{abstract}
Dr. Ataullah Khan Mehmood Wattoo
Assistant Professor Dept. of Law, International Islamic University Islamabad PO Box 1243, Sector H-10, Islamabad, Pakistan

Tel: 92-334-506-48-33_E-mail: wattoo888@gmail.com
\end{abstract}

Syed Mudassar Fida Gardazi

Assistant Professor Dept. of Law, University of Azad Jammu and Kashmir

Muzaffarabad

PO Box 13231, Muzaffarabad, Azad Jammu and Kashmir

Tel: 92-333-555-10-40Ｅ-mail: smgardazi@gmail.com

Received: November 22, 2017 Accepted: January 8, 2018 Published: January 11, 2018 doi: 10.5296/jsss.v5i1.12470 URL: http://doi.org/10.5296/jsss.v5i1.12470 


\section{Abstract}

Given the mass uprising and resistance in Libya, the international community intervened on humanitarian grounds in early 2011. Consequently, long-ruling leader Muammar Qaddafi's regime was overthrown. However, the Libya's crisis posed threat to international peace and security that is of increasing concern. In this context, this paper focuses on humanitarian intervention in Libya by the international community post 2011. It discusses various legal aspects of the emergency situation in Libya. It examines the nature of violence carried out by governmental regime and addresses the conflicting events as well as imposition of various obligations on people in Libya, e.g., the applicability of the Geneva Conventions of 1949 and legal aspects of the United Nations Security Council (UNSC) resolutions. Further, it analyses the question of jurisdiction of International Criminal Court (ICC) in this regard. Based on analysis of the UNSC Resolutions and situation in Libya, the paper analyses the national security of Pakistan in order to ascertain growing and contemporary challenges. The argument developed throughout this article is that all sort of revolutionary violence in Libya is not legally justified under norms of international law and effective implementation of the UNSC resolutions is considerable in relation to protection of the civilians on humanitarian basis. Nevertheless, humanitarian Intervention must comply with norms of International law in all situations. In terms of security of Pakistan, it argues that Pakistan actively seeks a peaceful international order and there is further need of improvement in national security to overcome contemporary challenges. The paper concludes that growing violence in Libya has demanded altruistic comeback from international communal.

Keywords: Libya conflict, Security Council resolutions, Humanitarian intervention, Violence, Jurisdiction of ICC, Security of Pakistan, Challenges

\section{Introduction}

Looking at Libya's revolutionary situation and violence, this paper focuses on the notion of humanitarian intervention in Libya post 2011. It discusses conflict's historic background and its effects in the light of United Nations Security Council (UNSC) Resolutions. It analyses the notion of humanitarian intervention from the historical purposes. It also addresses the question of International Criminal Court's (ICC) Jurisdiction and highlights the International legal obligations to 'respect' and 'protect' Civilians under International humanitarian law (IHL) in particular. The analysis the UNSC resolutions is considered and linked to the national security of Pakistan in order to ascertain contemporary challenges.

This article is divided into IX sections. Section I is introductory. Section II begins with analysis of historical background of conflict in Libya. It discusses the conditions and revolutionary violence in Libya post 2011. Section III examines the notion of humanitarian intervention and its aspects and consequences in Libya. Based on previous sections, the analysis of the UNSC resolutions in relation to Libya is given in section IV. Such analysis requires examination of the question of jurisdiction of ICC therefore Section V elaborates jurisdiction of ICC by analyzing the relevant legal framework.

It is necessary to explain relevant notions with linkage to the notion of humanitarian intervention therefore Section VI explains the notion of responsibility to 'protect' in the context of humanitarian Intervention in Libya. Based on analysis of the notion of 
humanitarian intervention, responsibility to 'protect' and resolutions of the UNSC in Libya, an attempt is made to link it with the situation of national security in Pakistan. Section VII analyses national security of Pakistan whereas Section VIII discusses contemporary challenges.. Brief conclusion of the discussion will then follow in Section IX.

\section{Historical Background}

In Libya, large-scale protests and demonstrations by the people erupted on 17 February, (2011). It is also known as "day of revolt" (Al-Jazeera News, 2011). On the other hand, Colonel Muammar Qaddafi's forces responded to these demonstrations by expending snipers, using artillery and helicopters on the crowds in order to disperse those (Meo, 2011). In this regard, freedom and rebel fighters have also protested and moved house to house by organizing alleys and blocking actions of Military forces" (Al-Jazeera News, 2011). While focusing on this situation and considering the gross violations of human rights, the UNSC has adopted resolution which has imposed no-fly zone (The UNSC Resolution: 1973, 2011).

This fighting was unstoppable and it has sustained for months. In August (2011), the rebels have taken back the area of Tripoli. The purpose was to get rid of the violations committed. The rebels also moved towards other areas, such as, Bani Walid and Surt. In these areas, Qaddafi's regime was strong (Fahim, 2011). In these circumstances, the rebels invaded in the other areas as well and punished supporters of Qaddafi. In fact, it was a bad situation under which human rights of innocent people were violated in length. People from Tawerga who moved from one city to another area were caught, detained and arrested (Fahim \& Nositter, 2011). Subject to the situation in Libya, the international community intervened in Libya on humanitarian basis.

However, the international community concerned for Libya in last decades. The concern was related to the human rights situation. In March, (2010) Libya had joined UN Human Rights Council (HRC). The HRC has issued several reports on situation of Libya. The HRC considered periodic reports from Libya and tried to take special measures for controlling situation therein. In January, (2011) The countries, such as, United States of America (USA) and Members of European Union (EU) were involved to propose measures for tackling situation in relation to gross human rights violations. These include death penalty, torture, freedom of expression and enforced disappearances (The UNGA Resolution, 2009).

The antigovernment protests continued and situation was out of control in Libya. The people who rebelled were attacked by the armed forces and gross human rights violations were committed which resulted in violence and massacre. Based on these violations, the UNSC has adopted resolution. This resolution called for freezing of assets, stop embargo and to refer the matter and crimes of Qaddafi to the ICC. Even some of his family members were also included (The UNGA Resolution, 2011). Meanwhile, the rebels declared their representative body known as Libyan Transitional National Council (LTNC). Considering this situation, the government of Qaddafi has officially announced that no one is allowed to participate against government and to that end if someone is willing to do must be responsible and will be killed accordingly. He declared that arms against government are strictly prohibited.

This humanitarian crisis resulted in adoption of Resolution 1973, which declared that the situation in Libya is controlled and civilian be protected in all respects (The UNGA 
Resolution, 2011). Even the Use of force was allowed to take necessary measures under Chapter VII of UN Charter to protect civilians. In light of the above resolution, intervention took place in Libya in different stages. The USA, United Kingdom (UK) and France have taken action at first instance. They launched the Operation Unified Protector under authority of North Atlantic treaty organization (NATO).

The foundation and legal basis for intervention was Resolution 1973 of the UNSC which specifically asserted that under Chapter VII the use of force and all necessary actions are allowed. This Resolution strengthened the role of International community towards intervention because it was grounded by the notion of humanitarian intervention (The UNGA Resolution, 2011). The nature of violence in Libya was case sensitive. It is necessary to examine the notion of humanitarian intervention and revolutionary violence in Libya; therefore next section is devoted on it.

\section{The Notion of Humanitarian Intervention}

It is important to note that the notion of Humanitarian intervention is not defined under international law in explicit terms. However, it simply means any intervention by one state or group in the jurisdiction of other state on humanitarian basis. It may include military means and the purpose is to prevent gross human rights violations in other state.

While explaining humanitarian intervention, other principles of International law are also relevant to the discussion, such as, prohibition on use of force and protection of human rights. It is interesting to note that these principles are enshrined in UN Charter. The former is in Article 2 (4) and the latter is mentioned in Article 1(3) of UN Charter. The latter is also supported by other articles. These principles also have force of customary International law (CIL) and states are required to respect, protect and fulfill in all circumstances. These principles are also recognized in international practice as well as legal literature.

Regarding Use of force, the International Court of Justice (ICJ) has delivered various judgments to confirm its prohibition, such as, The Corfu Channel Case, (1949). These principles are of fundamental nature and recognized as Jus Cogens or pre-emptory norms which cannot be denied by any state for any unjustified reason (Nicaragua vs. USA, 1986). There exist various different approaches in terms of recognition of use of force. For instance, first, the naturalists argue that if gross human rights violations are committed by one state then the other state has right to intervene. They have duty to intervene in order to protect people. This view of naturalists suggests that Humanitarian intervention is allowed even without the approval or consent of the UNSC. This theory is relied on moral political justification (Teson, 2003).

On the other hand, second, the legal positivists hold that the approval or consent of the UNSC under Chapter VII of the UN Charter is necessary for humanitarian intervention and if approval is not given it may amount to violation of international law. Thus it means that the only way for application of the notion of humanitarian intervention is by means of taking permission from the UNSC. This conclusion is based on a textual reading of the UN Charter and of a restrictive interpretation of opinio Juris and International practice (Joffe, 1994).

Another theory is of the "realist-constructivist" theory, "states that it is allowed under CIL if the purpose of the intervention do not contravene thereof. The purpose must be positive and 
for the protection of the people at large. It is because members of the international community acting as "trustees of the general interest" (Cassese, 1999). Their view thus legitimizes the notion if it has been taken in the interest of the international community or to preventing international crimes or fulfilling obligations erga omnes. For that purpose, they hold that the permission of the UNSC is unnecessary (Picone, 1995). This theory seems to be based on legal reasoning. By analyzing three doctrinal strands, it is stated that the status of the notion of humanitarian intervention under international law is unclear and confusing because of various theories and views. It is, therefore, necessary to examine situation in Libya and response of International community in this respect.

\subsection{Humanitarian Intervention in Libya}

The world has witnessed clarity in terms of intervention when the UNSC adopted Resolution 1973 on March, (2011). It was not the first time; the intervention has taken place even before Libya's intervention (BBC News, 2011). The intervention on the basis of unjustified grounds is evil and illegal as well. States are reluctant to affirm illegal intervention. Since 1990, the number of interventions is approximately 17 which include intervention in Iraq, Somalia, Bosnia, Kosovo and East Timor (Seybolt, 2007). However, such interventions are not clear rather created certain difficulties in terms of understanding it because the implementation is very weak and pathetic.

However, States have considered intervention as legal in the case of Libya. States argued that it was right. In this context, the UNSC has also drafted, approved and issued document in relation to humanitarian intervention and international coalition and implemented it accordingly (Rogers, 2011). On the basis of humanitarian grounds, the resolution no 1973 of UNSC has authorized and allowed Military force on in March 2011. This resolution has strengthened and supported the role of SC as legal and legitimate. The role of SC was justified for protective purposes (The UNSC Resolution: 1973, 2011).

The resolution aimed at protecting civilians by using of all necessary measures. While in its implementation, the resolution has lacked to reinforce and implement "responsibility to protect" doctrine as recognized in 2005 by the International community (The World Summit, 2005). In 2005, the international community stressed that states have obligation to protect in relation to genocide, crimes against humanity, war crimes etc. and that the $\mathrm{UN}$ is "prepared to take collective action, in a timely and decisive manner, through the Security Council... on a case-by-case basis... should peaceful means be inadequate and national authorities manifestly fail to protect their populations from genocide, war crimes, ethnic cleansing and crimes against humanity" (The World Summit, 2005). Based on these views, the next section analyses the UNSC Resolutions on Libya.

\section{Analysis of the UNSC Resolutions on Libya: An Overview}

In its $69^{\text {th }}$ meeting, on 26 February, 2011 UNSC has adopted Resolution 1970 (2011). Under this Resolution, The UNSC Demands an immediate end to the violence and calls for steps to fulfills the legitimate demands of the population. Further, the UNSC urges the Libyan authorities to: (a) "Act with the utmost restraint, respect human rights and international humanitarian law, and allow immediate access for international human rights monitors; (b) Ensure the safety of all foreign nationals and their assets and facilitate the departure of those 
wishing to leave the country; (c) Ensure the safe passage of humanitarian and medical supplies, and humanitarian agencies and workers, into the country; and (d) Immediately lift restrictions on all forms of media; Requests all Member States, to the extent possible, to cooperate in the evacuation of those foreign nationals wishing to leave the country.

In terms of ICC referral, the UNSC decides to refer the situation in the Libyan Arab Jamahiriya since 15 February, (2011) to the Prosecutor of the International Criminal Court". Further, the SC decides that "the Libyan authorities shall cooperate fully with and provide any necessary assistance to the Court and the Prosecutor pursuant to this resolution and, while recognizing that States not party to the Rome Statute have no obligation under the Statute, urges all States and concerned regional and other international organizations to cooperate fully with the Court and the Prosecutor".

The UNSC further declares that "all Member States shall immediately take the necessary measures to prevent the direct or indirect supply, sale or transfer to the Libyan Arab Jamahiriya, from or through their territories or by their nationals, or using their flag vessels or aircraft, of arms and related materiel of all types, including weapons and ammunition, military vehicles and equipment, paramilitary equipment, and spare parts for the aforementioned, and technical assistance, training, financial or other assistance, related to military activities or the provision, maintenance or use of any arms and related materiel, including the provision of armed mercenary personnel whether or not originating in their territories".

In the same year, recalling and following this Resolution, the UNSC has adopted Resolution 1973 in relation to Libya which speaks of taking special measures in order to protect civilians. This Resolution has also formed legal basis for humanitarian intervention. The UNSC, in terms of Protection of Civilians, "authorizes Member States that have notified the Secretary-General, acting nationally or through regional organizations or arrangements, and acting in cooperation with the Secretary-General, to take all necessary measures, notwithstanding paragraph 9 of resolution 1970 (2011), to protect civilians and civilian populated areas under threat of attack in the Libyan Arab Jamahiriya, including Benghazi, while excluding a foreign occupation force of any form on any part of Libyan territory, and requests the Member States concerned to inform the Secretary-General immediately of the measures they take pursuant to the authorization conferred by this paragraph which shall be immediately reported to the UNSC".

Another Resolution passed by the UNSC is Resolution 2146 in 2014 which imposed measures in Libya. Further, the UNSC has adopted Resolution 2208 on 5 March 2015. It is noteworthy that these all resolutions are related to Libya and the UNSC has acted under Chapter VII of the Charter. Another Resolution No: 2016 was passed by the UNSC on 27 October, 2011. It speaks of "positive developments" after Libyan civil War. It also settled down time for termination of Resolution 1973. Other Resolutions include resolutions 1267 (1999), 1373 (2001), 1624 (2005), 1989 (2011), 2161 (2014), 2170 (2014), 2174 (2014), 2178 (2014), 2195 (2014) and 2199 (2015). Under Resolution 2214 (2015), the UNSC by recalling all above-mentioned Resolutions condemned all extremist and fanatical acts of Levant, ISIL. The UNSC has also given presidential statements under which the acts of individuals including Ansar Al Charia, groups and entities involved or associated with ISL 
were condemned. The unSC also has emphasized on detailed approach in this regard.

Another Resolution 2213 (2015) was adopted by the SC on 27 March, 2015. Under this Resolution, the UNSC has recalled all previous resolutions and urged for engaging political parties to cooperate with the United Nations support mission in Libya (UNSMIL) and to facilitate special representative of UN in order to stabilize and control the situation in Libya. The purpose was to maintain international peace and security because the situation in Libya was problematic and life of the nation was endangered.

The UNSC has also adopted another important Resolution in this regard which is known as Resolution 2238 on 10 September, 2015. This Resolution speaks of unconditional and immediate ceasefire in Libya. The UNSC highlighted that situation is much problematic and cannot be controlled by military action only. However, it urged all political parties to act constructively with special representative and the UNSMIL in order to constitute unanimous agreement on the situation. The UNSC has also called for intra dialogue under this resolution. By virtue of above Resolution, the agreement was constituted and it was acknowledged by the UNSC under Resolution 2259 (2015) adopted on 23 December, 2015. The UNSC recalled previous resolutions and welcomed Morocco to form National accord Government under which Presidency Council and cabinet was formed. These all Resolutions were adopted in relation to Libya. The analysis of these Resolutions necessitates examination of question of jurisdiction of ICC therefore an effort is made to discuss it in the next section by analyzing relevant legal provisions.

\section{The Question of ICC's Jurisdiction}

The principal document in relation to ICC is the Rome Statute which establishes the jurisdiction of ICC and sets out conditions for exercise of jurisdiction in relation to war crimes, atrocities during war, massacre and genocide. The Rome Statute is fundamental document which elaborates the Court's jurisdiction in detail (Rome Statute, 1998). It is important to note that the ICC can exercise its jurisdiction in those cases which are mentioned in Rome Statute. For instance, the statute allows court to exercise jurisdiction over state parties to the statute or the situations or matters referred to the ICC. The jurisdiction of ICC can also be extended to the revolutionary situations beyond application of other bodies of International law, such as, International humanitarian law (IHL) (Scheffer, 1999).

Under article 14 of the Rome Statute, state parties may submit to a prosecutor for investigating into the matter to specify that whether or not criminals may be charged. Such submission or referral must specify the circumstances relevant and evidence in support thereof. States may act proprio motu (on its own pulse) in this regard (Rome Statute, 1998). Here question arises that what is the status of non-state parties to the Statute?

It is noteworthy to mention here that Libya neither adopted nor ratified the statute. However, the UNSC (acting under chapter VII of the Charter) has referred matter to the ICC on 26 February, (2011) (The UNSC Resolution: 1970, 2011). Taking into account such referral, it is presumed that the ICC has jurisdiction in the circumstances whereby situation is out of control and the matter has been referred to it by the UNSC. While taking into consideration the emergency situation in Libya, the ICC has issued warrants on 27 June, 2011. These warrants were issued for the Qaddafi, the then Military Intelligence Head 
(Abdullah-al-Senussi) and the then de facto Prime Minister (PM) (Saif-al-Islam Qaddafi). Thus the Court has exercised its jurisdiction on the basis of referral made by the UNSC (Prosecutor vs. Qaddafi, 2011).

Article 5 of the Rome Statute clearly specifies the Jurisdiction of the ICC under which certain crimes, such as, war crimes, genocide, aggression and crimes against humanity may be taken into consideration. The details of the crimes are further elaborated in the articles 6,7 and 8 of the statute under which other acts are also included in the definition of these crimes. The jurisdiction of ICC in the case of Libya is also justified under these articles because crimes against humanity and gross atrocities were committed. The life of the civilians was also not protected (Rome Statute, 1998).

Thus it is clear from the above that the ICC may exercise its jurisdiction in these circumstances as Libya had. It is important to note that the ICC has also extended its jurisdiction over crime of aggression. Keeping in view the Jurisdiction of ICC, the relevant governing framework of IHL and International Criminal Law (ICL) is analyzed in the upcoming section.

\subsection{Application of IHL and ICL}

The law regulating war is known as Law of armed conflict or IHL which is governed by Hague Regulations, (1907), Geneva Convention (GC), (1949) and Additional protocols to Geneva Conventions, (1977). States are required to adopt and ratify these conventions. In terms of the situation of Libya, it has ratified the core Conventions of IHL on 22 May, 1956 (The GCIV, 1949). The IHL is the regulating law in relation to armed conflict or all kinds of War (Kalshoven \& Zegveld, 2001). The IHL is codified after World War II in order to protect and save humanity from the evils of war. The Hague Regulations and Geneva Conventions elaborated rules regarding armed conflict. The Geneva Conventions, (1949) are also supplemented by Additional protocols of 1977. Though the definition of the term armed conflict is missing but it includes international as well as internal armed conflicts. For instance, internal armed conflict is elaborated in Article 3 of the GCIV which states and defines: "internal armed conflict as armed conflict not of an international character occurring in the territory of one of the High Contracting Parties."

The GCIV purely deals with the protection of Civilians and obliges states to protect civilians at their best. It also prohibits mistreatment or exploitation of the persons who no longer take part in hostilities. For instance, it protects persons placed as hors de combat (outside the fight), members of armed forces who no longer carry arms, wounded etc (ICRC, 2009). Thus the situation in Libya demanded the application of the provisions of IHL as well because a number of atrocities including murder, torture, maltreatment or mistreatment, mutilation etc which are protected under the provisions of GCIV, 1949. On the other hand, the provisions of Rome statute also correlate with the provisions of IHL and apply accordingly.

\subsubsection{Relevant Provisions of Rome Statute}

The Rome Statute purely deals with the international crimes including war crimes. It is important to note that the breach of Geneva Convention also amounts to war crime which is grounded under Rome Statute. It also seems that the ICC may exercise its jurisdiction in these cases. Further, the IHL and provisions of the ICC correlate with each other. Along with 
certain similarities in both bodies of law, there exist certain differences of provisions as well. For example, the Geneva Convention IV specifically relates to the armed conflict whereas the provisions of Rome Statute are general and applicable in all situations of significant magnitude. Example to that end is Article 8 of the Statute under which the Court has jurisdiction to try commission of large-scale crimes committed or when committed as a part of the plan or policy (Rome Statute, 1998).

Thus the jurisdiction of the ICC can also be justified under this article. The requirements for the exercise of jurisdiction of the court include the gross violations or breaches of the IHL. As mentioned in article 14 of the statute, the jurisdiction can be exercised if (i) state party refers matter to the court; (ii) on a referral made by the UNSC while acting under chapter VII of the UN Charter and (iii) if the prosecutor has started investigation into under article 15 of the Rome Statute.

\section{The Notion of Responsibility to Protect and Humanitarian Intervention}

While the use of force or humanitarian intervention and its authorization by the UNSC in Libya on the basis of responsibility to protect is welcomed as well as criticized by states and various Scholars of the legal arena. The Resolution 1973 is generally accepted by states with exceptions. The human rights of the people in Libya were protected and force was used against their own Government. The Secretary-General Ban Ki-moon, stated that "Resolution 1973 affirms, clearly and unequivocally, the international community's determination to fulfill its responsibility to protect civilians from violence perpetrated upon them by their own government" (The UNGA Resolution, 2011).

It means that the notion of responsibility to protect can be invoked by the international community. Scholars have criticized and drawn cautious conclusions. The enabling of the UNSC to act as exceptional case in Libya is acknowledged in general (Bellamy, 2011). However, on the other hand critiques were made in relation to nonappearance of the claim by SC that it had acted on the basis of the responsibility of the international community to protect (Chesterman, 2011). As far as Libyan crisis is concerned, it has combined and mixed number of factors which lead to unequivocally because most of the cases occurred simultaneously (Bellamy, 2011). For instance, the government of Libya itself has threatened to commit atrocities of the people, such as by Qaddafi, on the one hand and the time span of the violence committed, such as, it's beginning and conversion into civil war immediately, leaving short time for the SC decisions, on the other hand. Another factor in this context is the role of the international organizations, such as, the Gulf Cooperation Council (GCC) and the Organization of Islamic Cooperation (OIC) which together called for no-fly zone.

It is important to note that the Resolution 1973 contains responsibility of states to protect people which are already obligatory on states. The responsibility to protect has two elements, namely, states responsibility to protect and responsibility of the International community to protect civilians. However, it seems that it was not the consensual basis for intervention in Libya because of missing of the second part of the notion (Francioni \& Bakker, 2013). Following these factors, the China and Russia didn't veto the 1973 Resolution. Their non-participation has indeed facilitated the UNSC to act.

The direct involvement of the UNSC in domestic affairs of the states is questionable. The 
intervention only on the basis of humanity is pure in its strength. While the UN Security Council possesses the "primary responsibility for the maintenance of international peace and security its past practice demonstrates direct involvement in domestic conflicts" (Bassiouni, 2008).

The actions of the UNSC in Libya have demonstrated that number of events took place. For instance, the UNSC has established Commission for Libya and worked with the African Union (AU) (The UNSC Resolution: 2022, 2011). Further, these actions include referral of matter to the ICC, authorization of military force, freeze of asserts and restrictions of individuals. However, in this regard it is argued that the UNSC may establish ad hoc tribunals for controlling situation in Libya as it did in Rwanda and Yugoslavia in the shape of International Criminal tribunal for Rwanda (ICTR) and International Criminal tribunal for former Yugoslavia (ICTY) (Schabas, 2006).

The primary purpose of the UN is to maintain security and international peace. The unnecessary use of force by the parties is prohibited and must not be justified on the basis of humanity only. The doctrine of responsibility to protect requires its application in all aspects. The abstentions of states and not to ratify resolution paved way for the UNSC to act accordingly. The situation in Libya was unequivocal as well and the UNSC has acted and intervened on the basis of gross violations. However, such intervention must be supported by all states as well.

The notion of responsibility to protect requires protection of civilians in all respects. Even use of force has certain limitations and states are under obligations to promote, protect and fulfill basic human rights of the people under International human rights law (IHRL). The situation in Libya can be linked with the situation of the security in Pakistan. Although the UNSC neither has interfered nor intervened in Pakistan like Libya but the purpose here is to analyse the situation to explore challenges in national security of Pakistan. Therefore, the next section analyses the national security of Pakistan.

\section{National Security of Pakistan}

The term National Security can be defined as: "National Security is the ability to preserve the nation's physical integrity and territory, to maintain its economic relations with the rest of the world on reasonable terms to preserve its nature, institution, and governance from disruption from outside; and to control its borders" (Brown, 1983).

Pakistan's ideology believes and has faith on national, domestic, between nation's peace and international peace and security. Its foreign policy includes the provisions of peace for other states and respect for foreign nationals and humanity worldwide. However, Pakistan is victim of aggression and terrorism from decades. For example, Pakistan faced internal as well as external disturbances in relation to Kashmir dispute since 1947.

The opponent of the case has taken matter to the UNSC in 1948. As a result, the UNSC has passed Resolutions, particularly on 13 August, 1948 and $5^{\text {th }}$ January, 1948 calling for demilitarization of Military forces and holding a free and fair plebiscite in order to determine right to self-determination of Kashmiris under the UN auspices. Later, plebiscite is denied till date and demilitarization never took place in State of Jammu and Kashmir ( $\mathrm{J} \& \mathrm{~K}$ ) which is in fact violation of the norms of international law. India claims that Kashmir is its integral 
part whereas Kashmiris as well as Pakistanis reject and condemn it to date (Chishti, 2011). Indeed, Kashmir dispute is unfinished agenda of South Asia. Nevertheless, it is argued that it is need of the hour to resolve Kashmir dispute under auspices of the UN as promised so that the people of State of J \& K may exercise their right to self-determination, which is inherent, in order to determine their status and for enjoyment of their basic inalienable human rights.

Despite its internal and external threats to security and severe situation, Pakistan is a peaceful country in which majority of population is Muslims. Pakistan's concern in relation to security is internal as well as external defense. Pakistan is party to various international agreements including UN Charter and the Universal Declaration of human rights (UDHR), 1948. It adheres and affirms the principles of equality, non-discrimination, protection of human rights of people, peace and human dignity. Pakistan strongly condemns brutal acts of violence or gross human rights violations. Pakistan adheres that unlawful or by force acquisition of property or territory is prohibited.

Pakistan has always tried to strengthen relations with other countries by way of peace at regional and international level. Even it has concluded peace agreements for establishing peace. Thus peace is core to the national security of Pakistan and is inherent in its ideology and foreign policy. However, it has fought various wars with other countries. For example, Pakistan has fought the war of 1965 with India over the Kashmir dispute. The issue of Kashmir is central to its national and foreign policy because of unresolved status of the Kashmir since 1947.

Pakistan holds that India has occupied State of J \& K without any lawful authority since 1947 to date and India has violated basic human rights of the people of Kashmir. India claims that it is its integral part which is utopian idea because Muslims along with other minorities in Kashmir want freedom since years and sacrificed their lives for the freedom cause. However, the right to self-determination was never exercised by the people of Kashmir yet which is central to the provisions of UN charter, UDHR and other International instruments. It is argued that if intervention by the UNSC can be made in Libya on humanitarian basis and is justified then why not in Kashmir? The UNSC may play its effective role for solution of Kashmir dispute on humanitarian grounds. It is need of the hour to decide Kashmir dispute in light of the UNSC resolutions in order to protect basic human rights of the Kashmiris, the innocents.

Pakistan's national security is threatened when India has deployed its forces in $\mathrm{J} \& \mathrm{~K}$. However, the army men of Pakistan neither lost their nerves nor disappointed. They risked their lives to save others and till date they and fighting back. Pakistan has also fought war with India in 1971 whereby the national security was threatened because one part of Pakistan has been cut off which was a great loss.

These events have vital effects on security of Pakistan. However, Pakistan never compromised on its national sovereignty, territorial integrity and independence. Even after all these events, Pakistan has signed international agreements and instruments which speak of peace worldwide. Given effects of all events, Pakistan has capability to forestall aggression from all quarters. However, Pakistan has learnt certain lessons from all these historic occurrences and events. After September 11, Pakistan is fighting against evil of terrorism till date. The discussion reveals that Pakistan has always stood for peace and tried to resolve 
matters or conflicts with other states in peaceful manner. However, there exist certain challenges which need to be resolved by the political, legal, military and judicial as well as people in order to protect and strengthen economic, political, civil, social and cultural interests of Pakistan (Khan, 2017). The national security of Pakistan includes internal security which also needs to be protected at all levels.

\subsection{Internal/Domestic Security}

The internal security of Pakistan is linked with the National and international security. Pakistan has contributed for eliminating terrorism especially after the attacks of September 11, (2001). Pakistan has gone through the "War on Terror" and tried to eliminate it from its roots. The Global war on terror (GWOT) seeped into it gradually and marked its fabric of security. The war is not over yet but its effects are almost removed in a long struggle since 2001. In its entire length and breadth, this threat has stirred from borders of Pakistan and Afghanistan. It has certain challenges as well.

Because of terrorism and suicide attacks, Pakistan has suffered a lot. Military personnel as well as civilians were brutally killed. Almost 49 thousand lives have been taken up by terrorists (The Express Tribune, 2013). These are the approximate causalities and even more than that has been lost by Pakistan. After 2008, during operations a number of atrocities were committed throughout the country. It also has weakened the economic structure of Pakistan. The costs incurred by these causalities are about $\$ 100$ billion approximately (The Daily News, 2013).

Along with these costs three billion Afghan refugees are also bearded by Pakistan. However, Pakistan led assistance to US-led coalition in Afghanistan. The drone strikes and violence within country increased when Pakistan has participated in GWOT. It has suffered extremely in the shape of causalities and in terms of economy. Pakistan has also fought against Tehrik-e-Taliban Pakistan (TTP) and did military operations in tribal areas for elimination of terrorism. For instance, operation Zarb-e-Azb was design to maintain international peace and security. Terrorist attacks were not limited only to the Military security but it extended to the public places and civilians as well in the shape of suicide attacks. Even in this situation, Pakistan has fought for extremism and elimination of terrorism throughout the country. Various operations were designed to eliminate militants and to crush their hubs. It was done by the military effort in particular. However, there exists need for further improvement in addressing political, economic and social issues (Syed, 2014).

Despite facing crucial situations within country, Pakistan has never compromised on its territorial integrity and security. At international level, it has signed various treaties which pose obligations on Pakistan. For instance, the UNSC has laid down several laws for states in through its resolutions concerning terrorism, such as Resolution 1373, 1267 and 1540 and Pakistan has actively ratified and acted on it in order to avoid terrorism. These resolutions created obligations and responsibilities on states to put in effect counterterrorism actions put into practice effective legislation, to punish criminals and take necessary steps for eliminating terrorism. In this context Pakistan has also obligations to submit reports to the UNSC and it has submitted (The UNSC Resolution: 1624, 2005). 
For instance, changes by parliament in Anti-terrorism Act through legislation, law of custody or internment, de-radicalization programme and courts judgments constitute compliance of Pakistan towards fulfillment of Pakistan's obligations for submission of reports. The purpose is to protect national as well as international security and to eliminate acts of violence and terrorism at all levels. Along with these compliances and performances made by Pakistan, it is facing certain challenges as well which are discussed in the upcoming section.

\section{Challenges to Pakistan's National Security}

National Security is central to Pakistan's integrity and foreign policy. Despite Pakistan's participation in GWOT and its useful efforts for eliminating the evil of terrorism still it is facing certain challenges. The security of Pakistan has extensive challenges in relation to protection of the people by extrinsic threats. The GWOT has increased the challenges for Pakistan's security. The situation of the country is worsened by target killing and terrorist attacks. Pakistan has special geographic and geo-strategic location and that is influenced by other states in the region. The foreign nationals in Pakistan are almost protected by the Government at all levels. The main challenges regarding Pakistan's security in general are as follows:

- $\quad$ Tribalism and feudalism

- $\quad$ Political expediencies

- Weak governance and honest leadership

- $\quad$ Extremism and Radicalism

- Sectarianism.

The other challenges include:

\subsection{Religious Fanatism/Extremism and Hatred of Ideological Beliefs}

Religious extremism is one of the basic challenges in Pakistan's security. Although Islam is the peaceful religion but misuse and misinterpretation of the norms of Islamic law leads to the religious fanatism. Terrorist misinterpret the norms of Islamic law and weaken the security and stability within country. However, there is need of effective governance and sustainable rule of law in order to avoid extremism.

\subsection{Corruption and Nepotism in Governance}

In deed corruption is one of the elements which weaken the segments of society. In Pakistan, The National Reconciliation Ordinance has erstwhile on 28 November 2009. However, effective mechanism for trials of the corrupt leaders is necessary. In this regard, the courts have responsibility to convict victims and punish them if proven guilty. Meanwhile, nepotism has also increased in societies. For avoiding Nepotism, people are supposed to elect fair people so that they may contribute with competency and honesty in institutions of Pakistan. Rejection of corrupt and nepotism promoter leaders are need of the hour (Munoz, 2006).

\subsection{Internal Militants and Terrorists}

Along with external factors certain militant elements are existent within country as evident from the recent statement given by Minister of Foreign Affairs. The presence of Militant and terrorists in the areas of Karachi and Balochistan weaken and endanger the stability and security of Pakistan. Target Killing in Karachi must be controlled in order to stabilize security 
of the people of Pakistan. These Militants do not only kill forces of Pakistan but also groups and innocent people (Ali et al., 2015). Pakistan needs to sort out all these terrorists and punish them accordingly.

\subsection{Rule of Law and Its Effective Implementation}

Parliament is supposed to legislate according to the wishes of the people. Rule of law on the basis of equality and non-discrimination must be legislated in letter and spirit. There lies utmost need of effective implementation of the laws within country.

\subsection{Economic Crisis}

In line with economy of the country, Pakistan has suffered a lot from past decades. The rates of utility products are increased in the shape of inflation. The increase of taxes on commodities, property and services are significant. Along with these other challenges are as follows:

\subsection{Other Challenges}

The other challenges include: National non-integration and Sectarian Divergence and Ethnic polarization and Political Stability and poverty (Aziz, 2017).

\section{Conclusion}

From the preceding discussion, it is concluded that revolutionary violence in Libya began on 15 February, 2011. It began with number of protests and later converted into civil war. The UNSC intervened in Libya on the basis of the notion of Humanitarian intervention. In this regard the UNSC has issued various resolutions in order to control the crisis. The main resolution for intervention is Resolution 1973 adopted in 2011. The UNSC called for taking all necessary measures to protect civilians.

The UNSC also referred matter to ICC under Resolution: 1970 of 2011. As a result, the ICC has issued warrants against the concerned persons, such as, Qaddafi and his sons, in order to maintain peace and security. The Resolution also has required cooperation of the people of Libya in this regard. It is further affirmed by Resolution 2095 of 2013. The court intervened on the basis of severe nature of atrocities committed and to punish the criminals. However, the ICC can also intervene in the matter on the basis of Rome Statute. If domestic laws of the land and administrative machinery are sufficient to address the conflict, then there is no need of international element. Contrary to this, the situation in Libya was very crucial.

This paper has revealed that the notion of responsibility to protect must be applied in its true sense. It has elements, such as, responsibility to protect people and responsibility to protect by international community. The situation in Libya was justified on the basis of the notion of humanitarian intervention and responsibility to protect. The UNSC resolutions called for cooperation by the Government and people as well. By considering the nature of crisis, as a last resort, the international community intervened. However, it is argued that such intervention should have limitations. Not everything is fair in war. There should be check and balance for waging war or on use of force. Parties should require using force where necessary. All kinds of unnecessary use of force must be prohibited at all levels.

The paper also has highlighted that national security of Pakistan has internal as well as external threats. The external threats are significant on border areas and it must be stopped by international community on the basis of humanitarian intervention as in Libya. The presence 
of Militants within country poses threats to the security forces and people. The operations taken by armed forces against terrorism are applauded and need further improvement and assistance in this respect. Given the security issues of the Pakistan, it has certain challenges as well, such as, terrorism, suicide attacks, acts of sporadic violence, killing etc. The paper has concluded that Pakistan has challenges, such as, terrorism, sectarianism, weak governance, absence of implementation of Rule of law and external aggression. Along with these challenges Pakistan is facing political, economic and social challenges as well. In particular, the article has also argued that it is need of the hour to decide Kashmir dispute according to the wishes of Kashmiris as promised in 1948 i.e. by way of referendum or plebiscite under the auspices of the UN in order to protect basic human rights of Kashmiris. It is also need of the hour to address and overcome challenges for national security of Pakistan with immediate effect in order to establish security and peace.

\section{Acknowledgements}

The author wishes to thank Dr. Muhammad Mushtaq Ahmad, Chairman Department of Law, Faculty of Shariah and Law, International Islamic University Islamabad, Pakistan for useful insights on the subject and Prof. Dr. Marcel Brus, Chairman, Department of International law, University of Groningen, The Netherlands for valuable discussions. All errors remain solely with author(s).

\section{References}

Alexidze, A. L. (1981). Legal Nature of Jus Cogens in Contemporary International Law. Recueil des cours, 172, 219-270. https://doi.org/10.1163/ej.9789024727780.219-270

Ali, L. A., Naqvi, A. A., \& Qaisrani, I. H. (2015). Challenges to Democracy, Governance and National Unity. FWU Journal of Social Sciences, 9(1), 127-133.

Aziz, M. (2011). Pakistan: Traditional security challenges and response. Retrieved from https://discomaulvi.wordpress.com/2011/02/18/traditional-security-challenges-and-response/

Bassiouni, M. C. (2008). The New Wars and the Crisis of Compliance with the Law of Armed Conflict by Non-State Actors. J. Crim. L. \& Criminology, 711, 801-02.

Bellamy, A. J. (2011). Libya and the Responsibility to Protect: The Exception and the Norm. Ethics \& International Affairs, 25(3), 263-269. https://doi.org/10.1017/S0892679411000219

Brown, H. (1983). Thinking about National Security: Defense and Foreign policy in a dangerous World. Westview Press.

Cassese, A. (1999). Ex iniuria ius oritur: Are we Moving towards International Legitimation of Forcible Humanitarian Countermeasures in the World Community? European Journal of International Law, 10(1), 23-30. https://doi.org/10.1093/ejil/10.1.23

Chesterman, S. (2011). Leading from Behind: The Responsibility to Protect, the Obama Doctrine, and Humanitarian Intervention after Libya. Ethics \& International Affairs, 25(3), 279-285. https://doi.org/10.1017/S0892679411000190

Chishti, N. A. (2014). Pakistan's National Security: An Analytical Study. J. Asian Dev. Study, 3(3).

Fahim, K. (2011). Rebels Pour into Central Tripoli Square, Declaring Victory: Instead of Bloody Struggle, a Headlong Rush into a Cheering but Wary Capital. N.Y. Times, 22 August, 
p. 1.

Fahim, K., \& Nossiter, A. (2011). In Libya, Massacre Site is Cleaned Up, Not Investigated. N.Y. Times, 25 October, p. 4.

Francioni, F., \& Bakker, C. (2013). Responsibility to Protect, Humanitarian Intervention and Human Rights: Lessons from Libya to Mali. Transworld.

Islamic Republic of Iran v. United States of America, (the case concerning Oil Platforms), 6 November, (2003), The ICJ's Judgment, p. 6.

Joffe, G. (1994). Sovereignty and Intervention: The Perspective from the Developing World. Marianne Heiberg, London, Pinter, pp. 62-95.

Kalshoven, F., \& Zegveld, L. (2001). Constraints on the Waging of War: An Introduction to International Humanitarian Law. Int'l Comm. of the Red Cross, 11.

Khan, A. A. (2017). Security and Defence problems of Pakistan. Retrieved from http://www.defencejournal.com/april98/security\&defence1.htm

Meo, N. (2011). Gaddafi Sends in Snipers to Silence the Dissent. Sunday Telegraph.

Munoz, H. (2006). Democracy Rising: Assessing the Global Changes. New Delhi: Viva Books, p. 73.

Nicaragua v. United States of America, (the case concerning Military and Paramilitary Activities in and against Nicaragua), 27 June, (1986), The ICJ's Judgment, p. 14.

Picone, P. (1995). Interventi delle Nazioni Unite e obblighi erga omnes. Interventi delle Nazioni Unite e diritto internazionale, Padova, Cedam, pp. 517-578.

Report of International Committee of the Red Cross, (2009). Glossary: Terms Used in EHL 7. Rogers, S. (2011). NATO Operations in Libya: Data Journalism Breaks Down Which Country Does What. Guardian data blog, 31 October.

Schabas, W. A. (2006). The UN International Criminal Tribunals: The Former Yugoslavia, Rwanda, and Sierra Leone. Cambridge University Press, p. 48. https://doi.org/10.1017/CBO9780511617478

Scheffer, J. D. (1999). The International Criminal Court. Routledge Handbook of International Criminal Law, 67, 72.

Seybolt, T. B. (2007). Humanitarian Military Intervention: The Conditions for Success and Failure. Oxford University Press, p. 28.

Syed, M. (2014). Need for a Paradigm Shift in Security: Adopting Human Security in Pakistan. IPRI Journal, XIV(2), 79-97.

Teson, F. (2003). The Liberal Case for Humanitarian Intervention. Cambridge University Press, pp. 93-129. https://doi.org/10.1017/CBO9780511494000.004

The Al-Jazeera News. (2011). Battle for Libya: Key Moments. 19 November.

The BBC News. (2011). Syria Protests Online: "More than 2,900 Killed Overall”, 6 October.

The Daily News, (2013). 3 June, Islamabad.

The Express Tribune, (2013). 27 March, Islamabad.

The Geneva Convention Relative to the Protection of Civilian Persons in Time of War, (1949). 
The Rome Statute of the ICC, 17 July, (1998).

The UNSC Resolution No: 1973, (2011). U.N. Doc. S/RES/1973.

The UNGA Resolution of 12 January, (2009). Implementing the notion of Responsibility to Protect (A/63/677).

The UNGA Resolution of 26 February. (2011). Peace and security in Africa", (S/RES/1970).

The UNGA Resolution of 17 March, (2011). Resolution on Libya", (S/RES/1973).

The UNSC Resolution 1624, (2005). 14 September, U.N. Doc. S/RES/1624.

The UNGA Resolution of 17 March, (2011). Statement the Secretary-General on Libya.

The World Summit Outcome, (2005). G.A. Res. 60/L.1 138, U.N. Doc. A/RES/60/L.1.

United Kingdom of Great Britain and Northern Ireland v. Albania, (Corfu Channel case), 9 April, (1949), The ICJ's Judgment, p. 4.

\section{Copyright Disclaimer}

Copyright for this article is retained by the author(s), with first publication rights granted to the journal.

This is an open-access article distributed under the terms and conditions of the Creative Commons Attribution license (http://creativecommons.org/licenses/by/3.0/). 